\title{
INFLUENCE OF STRUCTURAL HETEROGENEITY ON THE PERFOMANCE OF THE MATERIAL OF LARGE DIAMETER PIPES IN COLD CLIMATES
}

\author{
N.O. SHAPOSHNIKOV ${ }^{1}$, B.S. ERMAKOV ${ }^{2}$, R.I. VALIAKHMETOV ${ }^{3} \&$ V.V. MIKHEEV $^{4}$ \\ ${ }^{1,2}$ National Technology Initiative Center for Advanced Manufacturing Technologies based on the Institute of Advanced \\ Manufacturing Technologies of Peter the Great St. Petersburg Polytechnic University Polytechnicheskaya, 29,
}

\author{
St.Petersburg, 195251, Russia \\ 3 “RN-BashNIPIneft” LTD \\ ${ }^{4}$ Severstal Management" PJSC
}

\begin{abstract}
The migration of extractive industries to the Arctic regions has set the task of ensuring the reliability and durability of pipeline systems in conditions of low climatic temperatures. It is established that the formation of low-temperature mechanical properties and crack resistance of $10 \mathrm{Mg} 2 \mathrm{VNb}$ steel is responsible for its structural state and residual rolling texture. The requirements prescribed in the current regulatory and technical documentation allow the formation of a wide range of microstructures and textures of steel rolling without setting strict requirements for grain size, banding, uneven grain size, non-metallic inclusions and residual texture of steel rolling, while pipes used for construction and repair of existing piping systems that meet regulatory requirements, for example, GOST R ISO 3183-2009, may be inoperative or limited in operability in low climatic temperatures. As a result of the analysis of the results obtained, it was confirmed that in order to increase the reliability and durability of pipeline systems operated in the Far North, it is necessary to refine the existing regulatory and technical base, including requirements for structural and textural states in the regulatory and technical documentation for pipe materials.

KEYWORDS: Low-Temperature Mechanical Properties, Arctic Infrastructure, Arctic Oil and Gas, Crack Resistance, Rolling Texture, Materials for Arctic Oil and Gas Fields, Cold Resistance
\end{abstract}

Received: Jun 09, 2020; Accepted: Jun 29, 2020; Published: Sep 26, 2020; Paper Id.: IJMPERDJUN20201447

\section{INTRODUCTION}

The oil and gas complex is one of the leading and most developed areas of the Russian industry. For decades, the production and processing of oil and gas has been the key to the successful development of the Russian Federation. Previously, the main deposits of fossil raw materials were located in the central regions of the country with the most convenient and well-developed logistics, both for the delivery of the initial product and the movement of finished products. However, at the turn of the twentieth century, the problem arose of a gradual decrease in the level of production at existing fields, an increase in the level of water cut and contamination of associated product fractions. The development of the mining industry was possible only with the development of new deposits located in the climatically unfavorable zones of the north and north-east of the country. During the preparation for operation, and then during the development of new deposits, a complex of problems arose that were not typical for the usual climatic zones. One of these problems is low and ultra-low climatic temperatures and the associated problem of increased equipment accidents. To ensure the reliability and durability of the equipment in the Arctic regions of the 
north and Siberia, it was necessary to develop new approaches to the certification of both equipment and materials from which it is made. The existing domestic and foreign regulatory and technical documentation practically does not provide for the testing of materials for pipes of infield and main pipelines, compressor units and other production equipment in conditions of low climatic temperatures (minus 60 - minus $70^{\circ} \mathrm{C}$ ), which sharply increases the failure of systems certified for operation in "familiar" climate conditions of middle latitudes. It is enough to analyze the main GOST for pipes of large diameters - GOST R ISO 3183-2009 [1], which is almost identical to the main regulatory documents adopted in oilproducing countries, for example, API Spec 5L: 2000 [2], etc. In these documents, there are practically no requirements for testing pipe materials at climatic temperatures typical for the Arctic region of the country.

One of the ways to improve the reliability of equipment operating at low climatic temperatures is to adjust the system of its alloying, for example, to increase the content of nickel, manganese and other elements in steels that contribute to grain refinement and a decrease in the ductile-brittle transition temperature. This path is very difficult, since the competition in the market of pipe manufacturers leads to the need to reduce the cost of production, which, in recent years, has been achieved mainly by de-alloying steel.

The second way is to improve the structural state of steels that are already being used. It is this path that has received the main development in all industrialized countries, including at enterprises of the Russian Federation. However, in order to improve the structure of pipe steels, it is necessary to solve the main problem - to determine the range of factors that have the main effect on the low-temperature properties of materials. It is necessary to evaluate and understand how, and with what combinations of actions, an increase in the low-temperature performance of pipe steels can be achieved. To date, this issue has not been finally resolved and requires fundamental research of the influence of both each individual factor and their joint impact.

These factors, of course, should include structural factors; first of all, it is necessary to assess the effect of banding and graininess of the structure, the effect of non-metallic inclusions - their composition, size and shape. It is necessary to evaluate the effect of residual effects on the structure of the thermoplastic deformation of steel, namely, the textural state of the pipe and sheet pipe billet.

\section{MATERIALS AND METHODS}

The work investigated the mechanical properties of high-strength pipe steel $10 \mathrm{Mg} 2 \mathrm{VNb}(10 \mathrm{Mg} 2 \mathrm{VNbAl})$. The welded pipe consists of $99 \%$ of the base metal and only $1 \%$ of the weld. Therefore, the main properties of pipes are provided not at pipe plants, but at metallurgical plants and on rolling mills during the formation of a pipe sheet blank, especially if it is obtained by the method of controlled rolling. High-strength low-alloy steels, which include the studied $10 \mathrm{Mg} 2 \mathrm{VNb}$, are characterized by a low carbon content (no more than $0.12 \%$ ). Silicon and manganese are introduced in quantities corresponding to steels of class 52-53 according to DIN 17 100. High-strength, low-alloy steels contain microalloying elements that, when combined heat and mechanical treatment during slab heating, hot rolling and cooling, affect the microstructure, grain size and properties of the steel. An analysis of the requirements for the manufacture of pipes of strength classes K42-K60 made of $10 \mathrm{Mg} 2 \mathrm{VNb}$ steel (TU 14-1-5506-2005) shows that the mechanical characteristics of the pipe metal are ensured by the regulated content of chromium, niobium and vanadium, low sulfur, phosphorus and nitrogen contents, as well as temperature-deformation mode of rolling. To ensure homogeneity of the steel and dissolution of microalloying elements, the slabs for rolling are heated to temperatures of $\sim 1200-1240{ }^{\circ} \mathrm{C}$. In the process of rolling in roughing groups of stands (total deformation of $15-40 \%$ ), it is necessary to transform the coarse cast structure into an 
austenitic structure with a uniform grain as a result of multiple complete recrystallization. In the process of finishing rolling with a limited number of reductions in a very short period of time (total deformation of $70-75 \%$ ), an austenite structure with a large number of ferrite grains must be obtained to ensure a fine ferrite grain.

The inhibition of the recrystallization of austenite in steel $10 \mathrm{Mg} 2 \mathrm{VNb}$ occurs both under the action of elements in a solid solution $(\mathrm{Nb}, \mathrm{V})$ and by means of niobium carbonitrides (carbides) released during deformation. The most effective element in this respect is niobium, its addition to steel in an amount of $0.05 \%$ increases the temperature of complete recrystallization (Tr) of austenite, below which it begins to slow down, from $\sim 800$ to $1000^{\circ} \mathrm{C}$; with a content of 0.08 $0.09 \%$ niobium - up to $1040-1050^{\circ} \mathrm{C}$. Since during rolling in the finishing group of stands the pauses between reductions are small, the release of carbonitrides occurs only partially, that is, some of the niobium and vanadium still remain in the solid solution, and during spraying, the phase composition of the steel is finally formed and the kinetics of the release of particles that provide precipitation hardening of the metal is set. To obtain a uniform phase composition of the metal, the rolling end temperature (Ter) must correspond to the lower part of the austenitic region in all sections of the strip [3].

It is known [3] that pipe steels are heterogeneous and imperfect both in composition and in their macro-, microand fine structure. The size, nature and degree of uniformity of the distribution of these imperfections determines the properties of steels, their behavior during processing, their strength and performance in various operating conditions. Inhomogeneity of the composition and imperfection of the structure of crystals and crystallites are associated with the initial composition of the alloy, the conditions of its crystallization (biographical imperfections), the formation of a streaky structure during thermal deformation, uneven grain size (the presence of grains of different sizes in the steel structure), which can be associated with liquation phenomena, or be deformation origin [3-5]. The analysis of the accident rate of pipeline systems during their operation in the harsh climatic conditions of the Arctic region showed that the destruction of pipelines occurs according to one of two main mechanisms. The first - the main one - is associated with problems with the quality of the pipe metal. During operation, the metal of pipelines experiences high loads caused by the movement or thawing of frozen soils, and the level of stresses in local areas can approach the values of the yield strength of steel. In the presence of high levels of structural heterogeneity, pearlite banding, nonmetallic inclusions in the pipe metal, crack-like defects arise and develop in these places. During further operation in these zones of the pipeline, a crack opens, which entails equipment failure and an accident, usually accompanied by a spill of transported products, environmental problems, high costs for containment of consequences, as well as lost profits for companies. So, for example, when analyzing the accident rate of pipelines of the Samotlor oilfield [6], it was shown that one of the main causes of damage is the formation of cold cracks, including in the heat-affected zone of the welded joint due to the increased tendency of the metal to brittle fracture at negative ambient temperatures (up to $-60^{\circ} \mathrm{C}$ ). In works [7-12], data on the destruction of pipeline systems after long-term operation in the conditions of Yakutia and other northern regions of the country are given. It is shown that the destruction of the pipe metal is associated with degradation processes caused by the inhomogeneity of the material structure.

An analysis of the accident rate of pipeline systems during their operation in the harsh climatic conditions of the Arctic region showed that one of the most probable reasons for pipeline failure is the lack of sufficient completeness of technical requirements for steels and pipe products operated in harsh climatic conditions. In the process of operation, the metal of the pipelines experiences high loads caused by the movement or thawing of frozen soils, and the level of stresses in local areas can approach the values of the yield strength of steel. In the presence of high levels of structural 
heterogeneity, pearlite banding, non-metallic inclusions in the pipe metal, crack-like defects arise and develop in these places. During further operation, it is in these zones of the pipeline that a crack opens, which entails equipment failure and an accident, usually accompanied by flooding of transported products, environmental problems, high costs for localizing the consequences, as well as lost profits for companies. So, for example, when analyzing the accident rate of pipelines of the Samotlor field [6], it was shown that one of the main causes of damage is the formation of cold cracks, including in the heat-affected zone of the welded joint due to the increased tendency of the metal to brittle destruction at negative ambient temperatures (up to $-60^{\circ} \mathrm{C}$ ). In works [7-12], data on the destruction of pipeline systems after long-term operation in the conditions of Yakutia and other northern regions of the country are given. It is shown that the destruction of the pipe metal is associated with degradation processes associated with the initial heterogeneity of the material structure.

In this work, we investigated the relationship between the structural features of $10 \mathrm{Mg} 2 \mathrm{VNb}$ pipe steel with its mechanical properties and crack resistance at low climatic temperatures. We have determined the extent to which the residual texture of rolling material affects the performance of steel. For research, templates were cut from two pipes with a diameter of $1420 \mathrm{~mm}$ and a wall thickness of $22 \mathrm{~mm}$, including both the base metal and the longitudinal welded joint (Fig. $1)$.

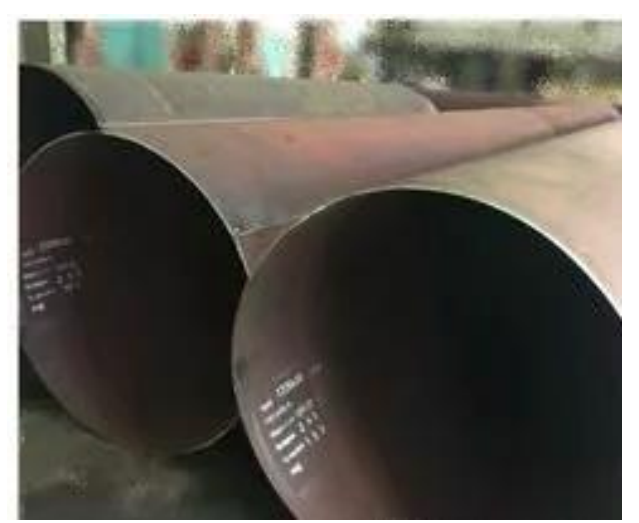

a)

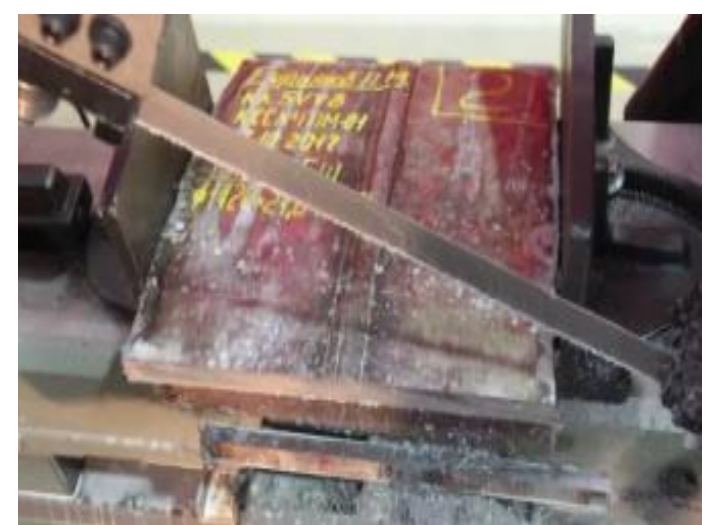

b)

Figure 1: Pipes 1420x22 mm made of Steel 10Mg2VNb (a), Cutting Template-Cutouts from the Pipe - Base Metal and Longitudinal Welded Joint (b).

Static tensile tests of cylindrical samples made of the base metal were carried out in accordance with GOST 149784 [13] on tensile testing machines of the servo-hydraulic type INSTRON 8801 with a maximum load capacity of $100 \mathrm{kN}$, equipped with hydraulic grippers and a control system that allows synchronous digital recording of the movement of the active gripper, tensile force and sample deformation. Static tensile tests of flat metal samples of a longitudinal welded joint were carried out on a similar testing equipment INSTRON 8806 with an ultimate load capacity of $500 \mathrm{kN}$, also equipped with hydraulic grippers and digital control and computer recording of load-elongation diagrams.

For tensile tests of the base metal, standard cylindrical samples of type IV No. 7 according to GOST 1497 were made from each pipe (transversely relative to the pipe axis). The type and dimensions of the specimens (diameter of the working part of the specimen $-5 \mathrm{~mm}$ ) ensured that there was no inadmissible preliminary editing of the template when cutting in the direction transverse to the pipe axes.

For tensile tests of welded joints, transverse flat proportional samples of type XIII according to GOST 6996 [14] were made from each pipe, the thickness of which was as close as possible to the thickness of the pipe. The reinforcement of the seam on the samples was removed mechanically (by planing across the seam) to the level of the base metal. 
Impact bending tests GOST 9454 [15] were subjected to samples from the base metal of pipes and samples from a longitudinal welded pipe joint at the following temperatures: $-5^{\circ} \mathrm{C},-20^{\circ} \mathrm{C},-40^{\circ} \mathrm{C},-60^{\circ} \mathrm{C}$. All tests were carried out on a verified pendulum impact tester INSTRON 600MPX (impact energy up to $600 \mathrm{~J}$, absolute measurement accuracy 0.78 J). The samples were cooled to the required temperature in a special thermostat, in which an alcohol solution was placed, cooled to the required temperature with liquid nitrogen. The temperature in the thermostat was controlled by a verified thermocouple with digital indication (the accuracy of the thermocouple readings $\pm 0.1^{\circ} \mathrm{C}$ ), which was fixed to the surface of one of the samples placed in the thermostat, included in the series of samples to be tested.

The assessment of crack resistance under static loading of samples from the base metal and samples from a longitudinal welded joint was carried out using INSTRON 8801. Samples with a fatigue crack were loaded according to the three-point bending pattern at temperatures of -10 and $-20^{\circ} \mathrm{C}$ with the definition of CTOD (crack tip opening displacement) corresponding to the beginning of its movement (BS 7448, ASTM E 647 and DIN EN ISO 15653). The characteristics of fracture toughness $\delta C$ (CTOD) were determined from the results of testing standard samples of the SENB type. The actual crack opening length (total notch length and fatigue notch enlargement length), as well as the distance from the crack front to the fusion line, was monitored using a ZEIZZ O-INSPECT 442 measuring complex upon completion of the sample test. The measurement accuracy maintained by the specified complex corresponds to $\pm 1 \mu \mathrm{m}$.

Investigations of the metal microstructure and fracture surfaces of the tested samples were carried out using optical microscopy and scanning electron microscopy in combination with X-ray microscopy analysis using TESCANVEGA and SUPRA 55VP WDS microscopes equipped with an energy dispersive X-ray spectrometer. The texture analysis of the base metal of all pipes was carried out using the Schultz texture analysis program (for reflection). The data obtained are the average values of the study of three samples per one control point. The analysis was carried out for reflections from a series of planes (110), (200), and (211). To obtain normalized straight pole figures and reverse pole figures [16], a reference textureless (powder) $\alpha$-Fe sample was taken.

\section{RESEARCH RESULTS AND DISCUSSION OF RESULTS}

The main normative and technical document governing the requirements for pipe metal for the oil and gas industry is GOST R ISO 3183-2009, therefore, when analyzing the chemical composition and mechanical properties of pipe metal, all the results obtained were checked for compliance with the relevant sections of this document.

Analysis of the chemical compositions of the pipe metal (Table 1) showed their full compliance with the requirements of GOST 19281-2014 Table 5, clause 9.2.2. GOST R ISO 3183-2009 - section "Welded pipes" line - L450M or X65M.

Table 1

\begin{tabular}{|c|c|c|c|c|c|c|c|}
\hline Pipe No. & \multicolumn{6}{|c|}{ Chemical Composition, Mass Fraction of the Element \% } \\
\hline \multirow{3}{*}{1} & $\mathrm{C}$ & $\mathrm{S}$ & $\mathrm{P}$ & $\mathrm{Mn}$ & $\mathrm{Cr}$ & $\mathrm{Si}$ & $\mathrm{Ni}$ \\
\cline { 2 - 8 } & 0,133 & 0,003 & 0,02 & 1,54 & 0,02 & 0,24 & 0,01 \\
\cline { 2 - 8 } & $\mathrm{Fe}$ & $\mathrm{Cu}$ & $\mathrm{N}$ & $\mathrm{Al}$ & $\mathrm{V}$ & $\mathrm{Ti}$ & $\mathrm{Nb}$ \\
\cline { 2 - 8 } & $\mathrm{Base}$ & 0,02 & $\leq 0,02$ & 0,03 & 0,08 & 0,02 & 0,04 \\
\hline \multirow{4}{*}{2} & $\mathrm{C}$ & $\mathrm{S}$ & $\mathrm{P}$ & $\mathrm{Mn}$ & $\mathrm{Cr}$ & $\mathrm{Si}$ & $\mathrm{Ni}$ \\
\cline { 2 - 8 } & 0,115 & 0,003 & 0,02 & 1,34 & 0,03 & 0,24 & 0,02 \\
\cline { 2 - 8 } & $\mathrm{Fe}$ & $\mathrm{Cu}$ & $\mathrm{N}$ & $\mathrm{Al}$ & $\mathrm{V}$ & $\mathrm{Ti}$ & $\mathrm{Nb}$ \\
\cline { 2 - 8 } & $\mathrm{Base}$ & 0,05 & $\leq 0,02$ & 0,04 & 0,05 & 0,03 & 0,04 \\
\hline
\end{tabular}


Table 2 shows the study of the mechanical properties of the base metal of the welded joint (seam, fusion boundary and heat-affected zone at a distance of $2 \mathrm{~mm}$ from the fusion boundary of the welded seam - softening zone) of a pipe made of $10 \mathrm{Mg} 2 \mathrm{VNb}$ steel. Bending tests of the longitudinal weld of pipes were also carried out and the calculation of the values of the carbon equivalent and CEIIW and the parameter Pcm $(\mathrm{CEPcm})$ was performed. To confirm the compliance of the pipe metal properties with the requirements of regulatory documents, the table contains excerpts from the requirements of GOST R ISO 3183-2009. The obtained properties of the pipe metal were checked for compliance with the requirements adopted for pipes of category PSL-2. It was found that in different sections of the pipe, properties that were different in level but met the requirements of GOST R ISO 3183-2009 were obtained.

Table 2: Mechanical Properties and Crack Resistance of Pipe Metal A. Impact Strength

\begin{tabular}{|c|c|c|c|c|c|}
\hline \multirow{2}{*}{\multicolumn{2}{|c|}{ Impact Toughness Test Results, J / cm2 }} & \multicolumn{4}{|c|}{ Temperature, oC } \\
\hline & & \multirow{2}{*}{$\frac{-5}{170}$} & \multirow{2}{*}{$\frac{-20}{162}$} & \multirow{2}{*}{$\frac{-40}{138}$} & \multirow{2}{*}{$\begin{array}{l}-60 \\
109\end{array}$} \\
\hline Pipe no. & 1 & & & & \\
\hline Base metal & 2 & 360 & 325 & 306 & 298 \\
\hline \multirow{2}{*}{$\begin{array}{l}\text { Pipe no. } \\
\text { Heat affected zone }\end{array}$} & 1 & 184 & 170 & 130 & 64 \\
\hline & 2 & 231 & 197 & 70 & 77 \\
\hline \multirow{2}{*}{$\begin{array}{cc}\text { Pipe no. } \\
\text { Fusion line } \\
\end{array}$} & 1 & 84 & 73 & 44 & 32 \\
\hline & 2 & 204 & 116 & 77 & 91 \\
\hline \multicolumn{6}{|c|}{$\begin{array}{l}\text { GOST R ISO 3183-2009. The minimum average value of the impact work when testing a pipe body with a } \\
\text { diameter of } 1219-1422 \mathrm{~mm} \text { and a test temperature of 00C should correspond to }-57 \mathrm{~J} / \mathrm{cm} 2 \text {, the weld metal } \\
\text { and its heat-affected zone }-33.8 \mathrm{~J} / \mathrm{cm} 2 \text { ) }\end{array}$} \\
\hline
\end{tabular}

\section{Single-Axle Static Tension}

Table

\begin{tabular}{|c|c|c|c|c|c|c|}
\hline \multirow{3}{*}{\multicolumn{2}{|c|}{ Static Tensile Test Results }} & \multicolumn{5}{|c|}{ Attribute } \\
\hline & & $\sigma 0,2$ & $\sigma \mathbf{B}$ & \multirow{2}{*}{$\begin{array}{c}\sigma 0,2 / \sigma \mathrm{B} \\
-\end{array}$} & $\delta 5$ & $\Psi$ \\
\hline & & \multicolumn{2}{|c|}{ MPa } & & \multicolumn{2}{|c|}{$\%$} \\
\hline \multirow{2}{*}{$\begin{array}{c}\text { Pipe no. } \\
\text { Base metal }\end{array}$} & 1 & 523 & 655 & 0,80 & 25 & 61 \\
\hline & 2 & 468 & 599 & 0,78 & 28 & 69 \\
\hline \multicolumn{2}{|c|}{ GOST R ISO 3183-2009 } & $415-565$ & $520-760$ & $\leq 0,93$ & & \\
\hline \multirow{3}{*}{$\begin{array}{c}\text { Pipe no. } \\
\text { Welded joint }\end{array}$} & & \multicolumn{3}{|c|}{ Place of destruction } & \multicolumn{2}{|c|}{$\sigma \mathrm{B}, \mathrm{MPa}$} \\
\hline & 1 & \multicolumn{3}{|c|}{ Heat affected zone } & \multicolumn{2}{|c|}{639} \\
\hline & 2 & \multicolumn{3}{|c|}{ Base metal } & \multicolumn{2}{|r|}{623} \\
\hline \multicolumn{2}{|c|}{ GOST R ISO 3183-2009 } & \multicolumn{3}{|c|}{ Weld $\sigma \mathrm{B}$} & \multicolumn{2}{|c|}{$\geq 520$} \\
\hline
\end{tabular}

\section{Crack Resistance}

Table

\begin{tabular}{|c|c|c|c|c|c|c|}
\hline \multirow{2}{*}{ Crack Resistance Test Results CTOD min, mm } & \multicolumn{3}{|c|}{ Base Metal } & \multicolumn{3}{c|}{ Welded Joint } \\
\cline { 3 - 7 } & & \multicolumn{5}{|c|}{ Temperature, oC } \\
\cline { 3 - 7 } & & $\mathbf{- 1 0}$ & $\mathbf{- 2 0}$ & $\mathbf{- 1 0}$ & $\mathbf{- 2 0}$ \\
\hline $\begin{array}{c}\text { Pipe no. } \\
\text { Base metal }\end{array}$ & 1 & 0.17 & 0,18 & 0,09 & 0,14 \\
\cline { 2 - 7 } & 2 & 0,79 & 0,75 & 0,44 & 0,38 \\
\hline \multicolumn{6}{|c|}{ GOST R ISO 3183-2009 regulated } \\
\hline
\end{tabular}

\section{Bend Tests}

Table

Bend test results. In accordance with GOST R ISO 3183-2009, "The opening of the weld and the formation of cracks in any part of the test sample is not allowed."

\begin{tabular}{|c|c|}
\hline $\begin{array}{c}\text { Template } \\
\text { No. }\end{array}$ & $\begin{array}{c}\text { Presence of } \\
\text { Unacceptable Defects }\end{array}$ \\
\hline 1 & Not found \\
\hline 2 & Not found \\
\hline
\end{tabular}




\section{Calculation of Parameters CEIIW и Pcm(CEPcm)}

Table

\begin{tabular}{|c|c|c|c|}
\hline \multirow{2}{*}{$\begin{array}{c}\text { Calculation of the Value of the Carbon Equivalent CEIIW and } \\
\text { Parameter Pcm(CEPcm) }\end{array}$} & Template No. & CEIIW & CEPcm \\
\cline { 2 - 4 } & 1 & 0,210 & 0.377 \\
\hline GOST R ISO 3183-2009 & 2 & 0,238 & 0.362 \\
\hline
\end{tabular}

As follows from the data presented, the steels of both pipes fully comply with the requirements for pipe materials - GOST R ISO 3183-2009 and for steel 10Mg2VNb - GOST 19281-2014 [17], however, a comparative analysis of the tables shows that the impact strength of pipe materials differs almost two or more times, which is especially noticeable at a temperature of minus $600 \mathrm{C}-109 \mathrm{~J} / \mathrm{cm} 2$ - the base metal of pipe 1 and $298 \mathrm{~J} / \mathrm{cm} 2$ - the base metal of pipe 2 ; the impact toughness of the metal in the fusion lines of steel seams - 32 and $91 \mathrm{~J} / \mathrm{cm} 2$, respectively; crack resistance of pipe metal (CTODmin, mm) at minus 200C - 0.18 and $075 \mathrm{~mm}$ - base metal and 0.14 and 0.28 - metal of welded joints. At the same time, the results of static tests practically did not reveal differences in the properties of steels (Table $2 \mathrm{~B}$ - static tension and Table 2D - bend tests): parameters CEIIW and Pcm(CEPcm) are also close and do not go beyond the requirements of GOST R ISO 3183-2009. Since the thermomechanical effect on the steel of both pipes is the same, then, probably, the reasons for such a significant difference in the impact toughness and crack resistance of the materials of the two pipes should be sought in the differences in their biographical structural state and subsequent permissible deviations in welding modes.

The microstructures of the base metal of the pipes were studied at magnifications from $\times 50$ to $\times 1000$. As follows from the photographs shown in Fig. 1, the microstructures of pipe steel in the longitudinal direction in the axial zone of the sheet are a matrix of polygonal, partially elongated along the direction of rolled ferrite and pearlite, located between the strips of the ferrite matrix.

The description of the streakiness of the steel structures was carried out on the basis of the requirements of GOST R 54570-2011 [18]. It has been established that in steel of pipe No. 1 the banding of the structure can be described as "a microstructure consisting of two components: an elongated, completely banded pearlite in an elongated banded ferrite matrix"; the structure of steel of pipe no. 2 is a microstructure consisting of two components: oriented, partially elongated, predominantly banded pearlite in a banded, predominantly equiaxed ferrite matrix.

Such structures in accordance with GOST 5640 [19] can be described as banded structures: 5-0 points - pipe 1 and 2-3 points - pipe 2. Based on the results of microstructure analysis, the following conclusions can be drawn. Both steels have a ferrite-pearlite structure. No inclusions of bainite or island martensite were found. The analysis revealed an insignificant amount of rounded inclusions located evenly over the area of the thin section. - fig. 2.

Based on the results of metallographic and microspectral studies, such inclusions were identified as inclusions formed by deoxidizing elements during steelmaking, such as aluminosilicates, calcium oxides and sulfides. The proportion of inclusions in the plane of the section of steel 1 is one and a half to two times higher than that of of steel of pipe no. 2.

It was found that the microstructures of steel pipes are a ferrite-pearlite mixture with pronounced banding of both phases - pipe 1; and the banding of pearlite with relatively equiaxed ferrite - pipe 2. 

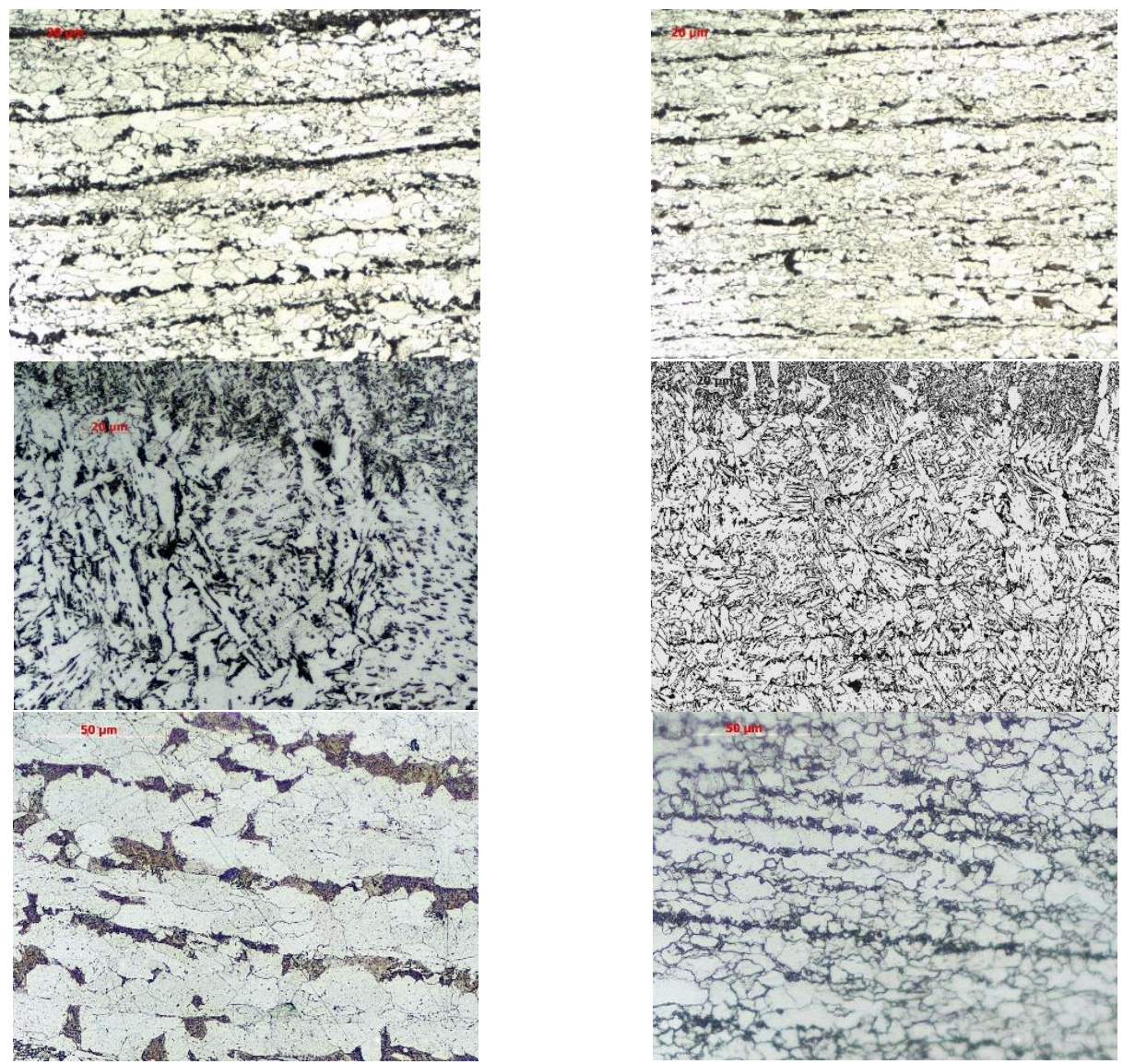

Figure 1: Metal of Pipes 1 and 2. On The Left - Pipe 1; On The Right - Pipe 2; Top Row Base Metal; The Second Row is the Fusion Line; The Third is a Heat-Affected Zone at a Distance of $2 \mathrm{Mm}$ from the Fusion Line. Magnification x500.

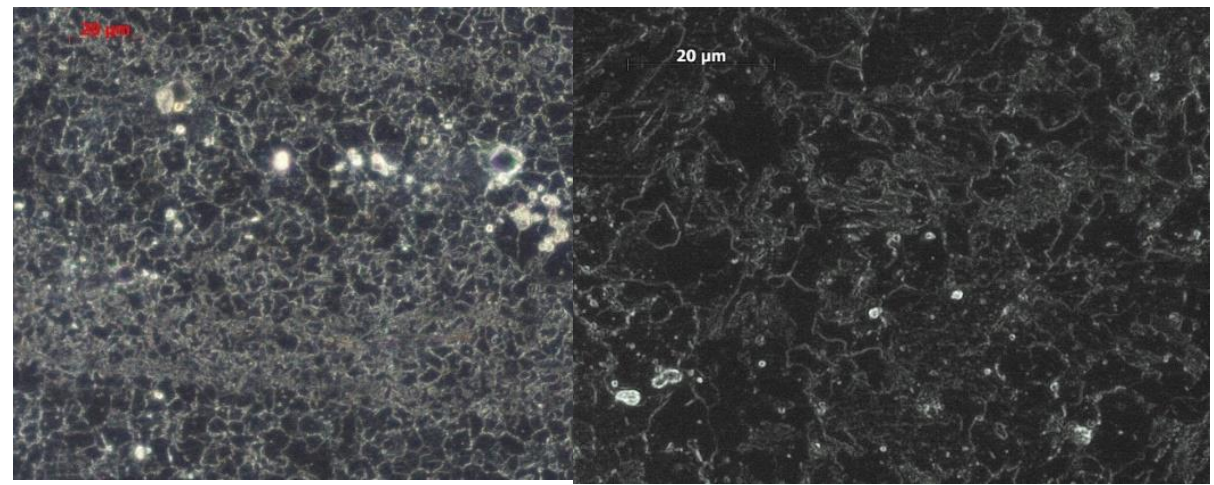

Figure 2: Non-Metallic Inclusions in the Base Metal of Pipe 1 (Left) and Pipe 2 (Right). Dark Field. Magnification x500.

When analyzing the microstructure of pipes along the thickness of the sheet, it was found that in the zone of one quarter of the thickness of the pipes, the banding of the structures is seen more clearly; in the middle cross section of the pipes, the influence of recrystallization processes with partial erosion of pearlite strips is noticeable. The microstructure of pipe steels at a quarter of the sheet thickness is a strongly deformed ferrite phase and alternating in the thickness direction with elongated pearlite regions. Due to the strong deformation in the near-surface layers of the metal, processes of recrystallization of individual ferrite grains take place. This type of structure is a consequence of the lowered rolling termination temperature and deformation of a significant volume of precipitated ferrite. In the central layers of the sheet, 
there is an uneven grain size of ferrite. Obviously, the uneven grain size is a consequence of the collective recrystallization of ferrite at higher temperatures in the center of the sheet [20].

The conclusion about the passage of recrystallization processes in the structures of steels is confirmed by an analysis of the grain sizes of the metal of both pipes. In the structures of both steels, areas of large weakly deformed grains that underwent recrystallization and areas with refined grains were found, and the intensity of the processes of collective recrystallization in of steel of pipe no. 1 proceeds much more intensively, which is confirmed by the data in Table 3. Also, the intensity of the recrystallization process depends on the zone - the average diameter of large grains in the middle section of the sheets of both steels is 1.3 - 1.5 times larger than in the section of one quarter of the thickness. The decomposition of austenite in the steel structures of both pipes occurred through the nucleation of ferrite grains at the boundaries of austenite crystals and their growth with the displacement of carbon into the zones of non-recrystallized austenite.

Table 3. Steel Grain Sizes of Pipes 1 and 2

\begin{tabular}{|c|c|c|c|c|}
\hline \multirow{2}{*}{ Subject of Control } & \multicolumn{4}{|c|}{ Grain Size, $\mu \mathrm{m}$} \\
\hline & \multicolumn{2}{|c|}{ Pipe no. 1} & \multicolumn{2}{|c|}{ Pipe no. 2} \\
\hline Section thickness & $1 / 4$ & $1 / 2$ & $1 / 4$ & $1 / 2$ \\
\hline Average diameter GOST 5639, $\mu \mathrm{m}$ & $6-9$ & $7-10$ & $6-7$ & $6-8$ \\
\hline Average number of grains per $0.01 \mathrm{~mm} 2 *$ & 137 & 123 & 247 & 231 \\
\hline Grain number according to GOST 5639 & 11 & $10-11$ & 12 & 11 \\
\hline Average diameter of the 50 "largest" grains in an area of $1 \mathrm{~mm} 2$ & 21 & 28 & 14,6 & 21 \\
\hline
\end{tabular}

* Note: Considering that all steels are fine-grained, the area for counting grains was chosen at the rate of 100x100 microns.

In addition, the central regions of the austenite grain are enriched with manganese. During hot rolling, the central portions of the former austenite grains are rolled into ellipsoids, which transform into pearlite upon subsequent cooling. Sections of these ellipsoids by thin sections perpendicular to the plane of the sheet give pearlite stripes of microstructure. Due to the enrichment in manganese of pearlite strips during the decomposition of austenite, they are resistant to heating.

When heated below $1000{ }^{\circ} \mathrm{C}$, pearlite banding degenerates into a row arrangement of pearlite grains along the former pearlite strip, which is associated with an increased content of manganese in it. Such a structure is typical for of steel of pipe no. 1 . An increase in heating up to $1100^{\circ} \mathrm{C}$ may disinhibition homogenization processes to obtain sufficient homogenization of manganese steel, with a partial collapse of pearlite banding that occurs in the structure of steel of pipe no. 2 .

Another factor influencing the mechanical properties is the orientation relationship between the phases and the matrix. The results of the study of the process of plastic deformation on the formation of the structural and textural states of the solid solution and the misorientation between the phases and the matrix of the steel showed that the texture patterns of the samples differ significantly from each other - in the rolling structure of steel pipe no. 2 there is an increase in the orientations of the shear texture (110) and a decrease in the angle scattering textures. The base metal of pipe no. 1 is in a state close to textureless. Thus, it can be concluded that it is the high degree of microstructure inhomogeneity and the peculiarities of the rolling texture that lead to reduced values of the impact toughness and brittle fracture resistance of the metal in the base metal of pipe no. 1.

The metal structure at the fusion line of the steels of both pipes is a Widmanstett structure with an expressed acicularity of ferrite. In the case of pipe steel 1, the Widmanstett structure score can be estimated as 4-5 
(GOST 5640); in the case of steel pipe 2 - as 2-3 points (Fig. 1). Such a high difference in the intensity and size of the acicular ferrite, first of all, depends on the cooling rate of the heat affected zone of the weld. The transition zones between the weld metal and the overheating zones are sharp, clearly delineated, the boundaries of the areas in the heat-affected zone are blurred and smoothly flow from one to another. Upon cooling in the heat-affected zones of both steels (in the areas of overheating adjacent to the fusion boundary), ferrite needles grow from the boundaries to the center of the austenite grains and have a pronounced orientation of the plane of the dodecahedron of the ferrite plate (110) and are located parallel to the planes of the octahedron of the austenite grain (111), and the close-packed directions (111) of the body-centered cubic structure of ferrite are parallel to the close-packed directions (110) of the face-centered cubic lattice of austenite. This mutual arrangement of the two phases during the recrystallization process provides the best conjugation between the two structures and the lowest surface energy. The reason for the reduced values of the impact toughness and crack resistance of the steel of the pipe no. 1 in relation to the steel of the pipe no. 2 in the zone of the fusion line of the steels is the conditions for the formation of the welded joint. A larger size of ferrite needles in steel pipe no. 1 indicates a larger size of austenite grains formed while heating during welding, within which acicular structures nucleate and develop, the sizes of which are always limited by the diameter of the initial austenite grain, which corresponds to the data given in $[21,22]$.

Based on an estimate size of ferrite needles in pipe steels, it seems possible to roughly estimate the size of austenite grains formed along the fusion boundary. For the steel of pipe no. 1, the austenite grain grade can be estimated as 2-3 with an average grain size of about $65 \mu \mathrm{m}$; for the steel of pipe no. 2 - 4 points, with an average austenite grain size of $48 \mu \mathrm{m}$. This difference in the size of austenite grains can be explained by the larger size of the ferrite grain in the steel of pipe no. 1 (Table 3).

Based on studies of the microstructure of the zones adjacent to the fusion boundary of welded joints in steels, it can be concluded that the value of the impact toughness and crack resistance of the metal of the fusion lines directly depends on the technological parameters of welding. Even a slight increase in the heat input allowed within the framework of the technological instruction leads to the growth of austenite grain in the fusion line of the weld, and upon accelerated cooling - to the formation of coarse-needle ferrite structures with increased fragility, especially in the zone of negative temperatures. The numerical values of the impact toughness and crack resistance of the metal of the fusion lines are a function of the size and shape of the needles of the ferrite grain, so in steel of pipe no. 2 the structure of the fusion line corresponds to 2-3 points of Widmanstett structures; in the case of steel of pipe no. 1 - 4-5 points.

The microstructures of the zone lagging $2 \mathrm{~mm}$ behind the fusion line of the pipe metal weld are also shown in Fig. 1. The zone located $2 \mathrm{~mm}$ from the fusion line is considered the most dangerous, since, depending on the welding modes and, accordingly, the realized cooling rates, in this area it is possible (except for the formation of large recrystallized ferrite grain) the course of complex physicochemical processes affecting on the shape and size of non-metallic inclusions.

The analysis of microstructures confirms that in this zone in the steel of both pipes, the structure recrystallized, which led to the enlargement of most of the ferrite grains. As a result, the microstructure, in large part, consists of large polygonal ferrite; residual bands of pearlite structure and a number of small ferrite grains are also visible. Separate inclusions of structurally free cementite were found within the boundaries of ferrite grains. Analysis of the microstructure of various sections of the investigated zone showed the presence of structural inhomogeneity, characteristic of multilayer welded joints. This heterogeneity is due to the phenomenon of auto-heat treatment, when each next applied layer of the weld heat treats the previous layers. In this case, in one part of the metal of the heat-affected zone of the weld seam, the 
metal can be normalized and a granular structure is formed, while the other part will be characterized by the presence of coarse lamellar structures. During the research, such structural features were noted as a sharp separation of ferrite grains in size - the grain size within one control field varied for steel of pipe no. 1 in the range from $35 \mu \mathrm{m}$ to $5.5 \mu \mathrm{m}$; for steel of pipe no. 2 - from 20 to $4 \mu \mathrm{m}$. Significant differences in the size of ferrite grains in different control fields and the precipitation of fine particles of structurally free cementite within the grain boundaries are noted.

\section{CONCLUSIONS}

The conducted experiments proved the leading role of the structural state of $10 \mathrm{Mg} 2 \mathrm{VNb}$ steel in the formation of lowtemperature impact toughness and crack resistance. It is shown that the requirements specified in the current normative and technical documentation make it possible to form a fairly wide range of microstructures and textures for rolling steel without limiting or setting strict requirements for the grain size, banding, grain difference, non-metallic inclusions and residual texture of rolling steel. Thus, pipes used for the construction and repair of existing pipeline systems that fully comply with the requirements, for example, such a document as GOST R ISO 3183-2009, may be inoperative or partially operable in low climatic temperatures. As a result of the analysis of the obtained results of the study, it was shown that in order to improve the reliability and durability of pipeline systems operated in the Far North and Siberia, it is necessary to refine the existing regulatory and technical base, including requirements for structural and textural constraints in the requirements for pipe materials.

Analysis of the research results also allows us to draw the following conclusions:

- The current normative and technical documentation is focused on the safety and reliability of pipeline operation in the moderately cold climate of the middle zone of the Russian Federation and requires improvement for use in the operation of pipelines in the Arctic and other circumpolar zones.

- Structural heterogeneity - banding, uneven grain size, orientational relationships between phases and matrix practically without changing the strength and plastic properties of the base metal of pipes, lead to a sharp decrease in their impact strength and crack resistance at low climatic temperatures.

- Analysis of the welded joint of a longitudinal seam pipe revealed the features of the formation of the metal structure in the heat-affected zone of the welded seam. It is shown that a Widmanstett structure is formed in the weld fusion line, and the size and shape of the ferrite needles directly depend on the size of the initial austenite grains and the level of grain size variation of the ferrite component.

- An urgent task is the development of fundamentally new generations of pipe products of the northern climatic design, which have a specific set of properties, for the achievement of which new steel alloying compositions and structural composition will be developed.

\section{REFERENCES}

1. GOST R ISO 3183-2009 [1] «Trubyi stalnyie dlya truboprovodov neftyanoy i gazovoy promyishlennosti. Obschie tehnicheskie usloviya». M., Standartinform, 2011, $113 \mathrm{~s}$.

2. API Spec. 5L/ISO 3183:2009 "Neftegazovaya promyishlennost - Trubyi stalnyie dlya truboprovodnyih transportnyih sistem". Tehnicheskie uslo-viya na trubyi dlya truboprovodov. Otdel razvedki i dobyichi. - izd. 42. 2000 Dallas. USA. 
3. Rudskoy A. I. Fizicheskoe i matematicheskoe modelirovanie formiro-vaniya strukturyi i svoystv staley pri goryachey prokatke. Razrabotka so-vremennyih tehnologiy goryachey prokatki staley s garantiruemyim urovnem mehanicheskih svoystv / A. I. Rudskoy, N. G. Kolbasnikov // Innovatsion-nyie tehnologii v metallurgii i mashinostroenii : materialyi 6-y mezhdu-narodnoy molodezhnoy nauchno-prakticheskoy konferentsii «Innovatsion-nyie tehnologii v metallurgii i mashinostroenii. Uralskaya nauchno-pedagogicheskaya shkola imeni professora A. F. Golovina», [g. Ekaterin-burg, 29 oktyabrya - 1 noyabrya 2012 g.]. —Ekaterinburg : Izd-vo Ural. un-ta, 2013. - S. 331-344.

4. Solntsev Yu.P., Ermakov B.S. i dr. Metallyi i splavyi. Spravochnik. Pod obschey redaktsiey Yu.P. Solntseva. - SPb. Professional, 2005. - 998 s.

5. Ermakov B.S., Shaposhnikov N.O. Vliyanie tehnologicheskih faktorov na formirovanie svoystv metalla trub magistralnyih nefteprovodov // Me-tallurg, 8(62), S. 39-43, 2018.

6. Muhin M.Yu. Tehnologicheskie osnovyi obespecheniya nadezhnosti nefte-promyislovyih truboprovodov Samotlorskogo mestorozhdeniya. Avtorefe-rat nauch.dokl.na soisk.uch.st.k.t.n, 2001, 18 s.

7. A.M. Bolshakov, A.S.Syiromyatnikova. Razrusheniya i povrezhdeniya ob'-ektov magistralnogo gazoprovoda pri dlitelnoy ekspluatatsii v uslo-viyah Arktiki./ Nauka i obrazovanie, 2015, \#4, s.95-99

8. Bolshakov A.M., Golikov N.I., Alekseev A.A. i dr. Analiz avariy i otkazov truboprovodov i oborudovaniya neftyanoy $i$ gazovoy promyishlen-nosti v usloviyah Severa. Chast 1. Razrusheniya i povrezhdeniya pri dli-telnoy ekspluatatsii ob'ektov neftyanoy $i$ gazovoy promyishlennosti // Ga-zovaya promyishlennost. - 2007. -\#7. - S. 89-91.

9. Ermolenko Yu.G., Bolshakov A.M., Cheremkin M.K., Tugi R.E. O tehni-cheskom sostoyanii magistralnyih gazoprovodov Yakutii // Bezopasnost truda v promyishlennosti. - 2003. - \#10. - S. 5-7. 3. 5. Sleptsov O.I., Lyiglaev A.V., Bolshakov A.M., Sintsov S.A. Diagnostika i bezopasnost stareyuschih bolshih mehanicheskih sistem, eksplutiruyuschihsya v usloviyah Severa: Problema i puti resheniya // Defektoskopiya. -2008. -\#6. - S. 31-41

10. Chuhareva N.V., Tihonova T.V., Mironov S.A. Analiz prichin avariy-nyih situatsiy pri ekspluatatsii magistralnyih truboprovodov v uslovi-yah Kraynego Severa v periods 2000 po 2010 g. // Elektronnyiy nauchnyiy zhurnal «Neftegazovoe delo». - 2011. - \# 3. - S. 231-243.

11. Filippov G.A., Livanova O.V., Dmitriev V.F. Degradatsiya svoystv me-talla pri dlitelnoy ekspluatatsii magistralnyih truboprovodov // Stal. - 2003. - \# 2. - S. 84-87.

12. Mahutov N. A., Permyakov V.N., Kravtsova Yu.A., Botvina L.R. Otsenka sostoyaniya materiala produktoprovoda posle ego dlitelnoy ekspluatatsii // Zavodskaya laboratoriya. Diagnostika materialov. - 2007. - T.73, \# 2. - S. 35-43.

13. GOST 1497-84. Metallyi. Metodyi ispyitaniy na rastyazhenie M., Stan-dartinform, 2008, 22 s.

14. GOST 6996-66. Svarnyie soedineniya. Metodyi opredeleniya mehaniche-skih svoystv. M., Standartinform, 2006,66 s.

15. GOST 9454-78. "Metallyi. Metod ispyitaniya na udarnyiy izgib pri po-nizhennyih, komnatnoy i povyishennyih .temperaturah. M., Standartinform, 2008, $9 \mathrm{~s}$.

16. Ermakov B.S., Alkhimenko A.A., Shaposhnikov N.O., Tsvetkov A.S., Shirokov A.V. Issledovanie kristallograficheskoy teksturyi trubnoy stali // Pisma o materialah. - 2020. T. 10. \# 1 (37). - S. 48-53.

17. GOST 19281-2014. Prokat povyishennoy prochnosti. Obschie tehniche-skie usloviya. M., Standartinform, 2015,47 s.

18. GOST R 54570-2011 «Stal. Metodyi otsenki stepeni poloschatosti ili orientatsii mikrostruktur». M., Standartinform, 2012,32

19. GOST 5640-68. Metallograficheskiy metod otsenki mikrostrukturyi listov i lentyi M., Izdatelstvo standartov., 1988, 8 s..20. 
20. Ermakov B.S., Shaposhnikov N.O. Effect of production factors on main oil pipeline pipe metal property formation // Metallurgist. 2018. \#62 (7-8). P. 766-771. DOI: 10.1007/s11015-018-0718-7.

21. Fedoseeva E.M. Mehanicheskaya i strukturnaya neodnorodnost svarnyih soedineniy stali H65./Vestnik Permskogo NIPU. Mashinostroenie, Me-tallovedenie. 2016,t.18, \#2, s. 76-87.

22. Sheksheev M.A. Osobennosti strukturyi i svoystva zonyi termicheskogo vliyaniya svarnyih soedineniy staley klassa prochnosti K56. Diss. na so-isk.uch.st.k.t.n. Magnitogorsk, 2013, 122 s. 

